
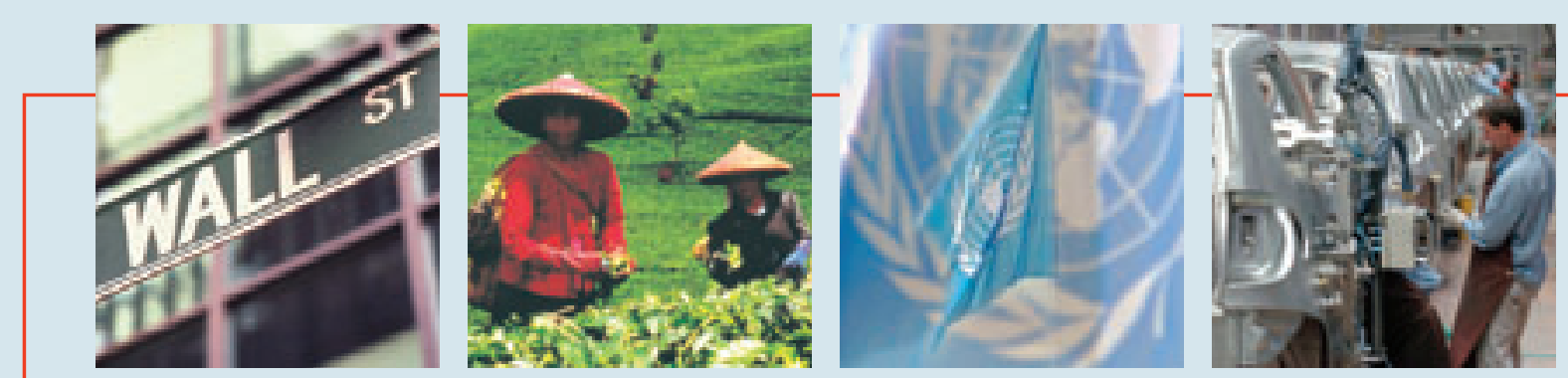

Dialogueon Globalization

OCCASIONAL PAPERS

GENEVA

N³0 / April 2007

Robert Howse and Ruti G. Teitel

\title{
Beyond the Divide
}

The Covenant on Economic, Social and Cultural Rights and the World Trade Organization

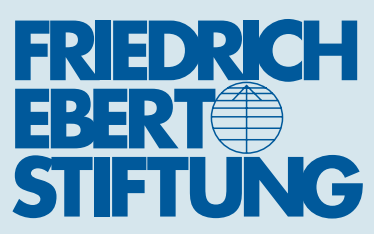




\section{Dialogue on Globalization}

Dialogue on Globalization contributes to the international debate on globalization through conferences, workshops and publications - as part of the international work of the Friedrich-Ebert-Stiftung (FES). Dialogue on Globalization is based on the premise that globalization can be shaped into a direction that promotes peace, democracy and social justice. Dialogue on Globalization addresses "movers and shakers" both in developing countries and in the industrialized parts of the world, i.e. politicians, trade unionists, government officials, businesspeople, and journalists as well as representatives from NGOs, international organizations, and academia.

Dialogue on Globalization is co-ordinated by the head office of the Friedrich-Ebert-Stiftung in Berlin and by the FES offices in New York and Geneva. The programme intensively draws on the international network of the Friedrich-Ebert-Stiftung - a German non-profit institution committed to the principles of social democracy - with offices, programmes and partners in more than 100 countries.

This Occasional Paper is published by the Geneva office of the Friedrich-Ebert-Stiftung.

April 2007

\section{Table of Contents:}

1. Preface 3

2. Executive Summary 4

3. Introduction

4. Domestic Policy Space 12

4.1. The Direct Effects on Social, Economic and Cultural Rights of Reduction in Trade Barriers

5. The Rights to Work, Health and Food in Interaction with the WTO Regime 14

5.1. The Right to Work

5.1.1. Human Security, International Trade, and Worker Dislocation 14

5.1.2. Subsidies 15

5.1.3. Human Security, Trade in People, and the General Agreement on Trade in Services

5.2. The Right to Health 20

5.2.1. Trade in Goods $\quad 20$

5.2.2. Domestically-Prohibited Products $\quad 21$

5.2.3. The Right to Health, the TRIPS Agreement, and Access to $\begin{array}{ll}\text { Essential Medicines } & 22\end{array}$

5.3. The Right to Food $\quad 25$

6. Conclusion 28

7. List of Abbreviations and Acronyms 29 


\section{Preface}

Trade Policies and Human Rights issues are usually discussed in isolation. Yet, the mutual impact is not deniable, which makes it mandatory for researchers and politicians in both areas to strengthen their awareness of the existing links.

Often a discussion of those links ends up in dogmatic positions. One side declares the blessing of free markets in a frame of "rising tide" theories, which see the promotion of human rights as an automatic result of economic growth. The other side sees this "rising tide" rather like a tsunami, washing away every boat that is not strong enough to withstand the colossal changes.

Therefore, for some, markets are the solution for the promotion and protection of Human Rights, while others see a free market as the reason of all evil, calling for an abolition of the World Trade Organization and international free trade agreements without looking thoroughly into their substance.

Robert Howse and Ruti Teitel deliver in this paper a discussion of specific features of the International Covenant on Economic, Social and Cultural Rights and the regulatory framework of the World Trade Organization. They analyze the possible negative impacts the international trade system may have on the enjoyment of economic, social and cultural rights and show ways to avoid those negative effects within the existing trade system by means of applying WTO rules.

This paper resulted from a workshop, which was jointly organized by the Secretariat of the UN Committee on Economic, Social and Cultural Rights and the Geneva Office of the Friedrich-Ebert-Stiftung. The workshop aimed at strengthening the impact of the Committee on trade policies and was exploring possibilities for the Committee, to take an active role and enclose trade issues into their revision of State's reports on their compliance with the Covenant. It also represents a further continuation of the collaboration between the Committee on Economic, Social and Cultural Rights and FES Geneva.

At FES Geneva, we attach high importance to the achievement of a bridging between the topics of human rights and trade, which both form major pillars of our work. In this respect, the authors provide important findings for human rights advocates and trade politicians alike. The major strength of their paper is that it shows problems which may arise from trade agreements but at the same time points out the flexibilities given in WTO rules which, if interpreted correctly, allow for an effective protection and active promotion of human rights.

\section{Felix Kirchmeier}

Geneva Office

Friedrich-Ebert-Stiftung 


\section{Executive Summary}

The legal, institutional and policy cultures of international human rights law and of international trade, financial and investment law have developed largely in isolation from one another. At the same time, as a matter of international law, both the International Covenant on Economic, Social and Economic Rights (ICESCR) and the World Trade Organization (WTO) are, in the first instance, treaty regimes.

Treaty norms in the ICESCR have an equal legal status to those in the WTO. A large majority of states are signatories to both the core WTO treaties (the so-called Covered Agreements) and the ICESCR. Reconstructing globalization on the basis of a human rights consciousness, and in particular with a view to fully realizing the vision of the ICESCR is a daunting task, which would need to engage many policy disciplines and many institutions. A short to medium term strategy is needed to identify some fairly precise and specific interconnections between the legal concepts and doctrines in the treaty texts of both regimes.

As international lawyers whose collective expertise extends across both regimes, the authors conceive the challenge as a legal question of the interaction of treaty norms. The authors focus on those aspects of economic, social and cultural rights that are most directly linked to human security, a fundamental value also acknowledged in various ways in the WTO Agreements and their interpretation. Accordingly, they examine aspects of the right to work, the right to health and the right to food and the impact of WTO rules and their interpretation. 


\section{Introduction}

Since the end of the Cold War, two main visions have guided the evolution of international law and institutions - the vision of human rights and humanity and that of economic globalization. Both visions have offered challenges to traditional understandings of sovereignty: both have given a new significance to non-state actors in the evolution and implementation of international law. Both have often given rise to demands and aspirations to global politics and/or constitutionalism as well as new relationships between local, national, regional and global levels of governance.

However the legal, institutional and policy cultures of international human rights law and of international trade, financial and investment law have developed largely in isolation from one another.

As a matter of international law, both the International Covenant on Economic, Social and Economic Rights (ICESCR) and the WTO are, in the first instance, treaty regimes. A fundamental structural characteristic of the international legal system is that of decentralization without hierarchy. ${ }^{1}$ Treaty norms in the ICESCR have an equal legal status to those in the WTO. A large majority of states are signatories to both the WTO Single Undertaking (the core WTO treaties) and the ICESCR. The principle of decentralization without hierarchy, along with that of giving full effect to international obligations, implies the need to interpret and to develop these regimes in a complementary and consistent fashion to the extent possible. As the Report of the International Law Commission (ILC) on fragmentation of international law notes: "In international law, there is a strong presumption against normative conflict." ${ }^{2}$

Since the WTO Seattle Ministerial, now almost a decade ago, there has been a concerted effort in the international human rights community, by activists, academics, and the Office of the High Commissioner to overcome this isolationism, attempting to understand how trade affects the realization of human rights and what implications human rights obligations have for the interpretation and negotiation of trade agreements. ${ }^{3}$

It is fair to say that these efforts have not been matched by a comparable openness on the part of the international trade law and policy community: WTO negotiations in the Doha Round are occurring without any explicit reference to human rights.

1 See generally, International Law Commission, "Fragmentation of International Law: Difficulties Arising from the Diversification and Expansion of International Law,” Report of the Study Group of the International Law Commission, finalized by Martti Koskenniemi.

2 Ibid., paragraph 37.

3 See for example Liberalization of trade in services and human rights, Report of the High Commissioner for Human Rights (E/CN.4/Sub.2/2002/9). Globalization and its impact on the full enjoyment of human rights; Report of the High Commissioner for Human Rights (E/CN.4/2002/54). The report considers the WTO's Agreement on Agriculture; The Human rights, trade and investment, Report of the High Commissioner for Human Rights, (E/CN.4/Sub.2/2003/9).impact of the TRIPS Agreement on the Enjoyment of all Human Rights, report of the High Commissioner for Human Rights, (E/CN.4/Sub.2/2001/13).

\section{The legal, institutional and policy cultures of international human rights law and of international trade, financial and investment law have developed largely in isolation from one another.}

WTO negotiations in the Doha Round are occurring without any explicit reference to human rights. 
The Cold War legacy of economic and social rights brought with it an association with discredited collectivist approaches to economic and social organization; the concept was often viewed as polarizing along East/West, North/South fault lines; this is a heritage that must be overcome if economic and social rights are to gain purchase in the international economic regimes. The conventional economic policy ideology prevalent in the international trade law and policy knowledge communities views the issues surrounding access to essential services, food, housing, and healthcare as a matter of trade offs under scarcity. From that perspective, there may be a tension between the role of the market in generating the wealth necessary to obtain these goods and the capacity to guarantee wider access to them through redistribution; thus, speaking of rights in these contexts is often viewed as incoherent, mere posturing or wishful thinking. The problem here is a lack of awareness in the international trade policy community about how economic and social rights have been interpreted and elaborated in the policy and practice of the international human rights institutions.

There is an absence today of a plausible, agreed normative economic framework that can inform debates about globalization as well as related domestic reforms.

A joint study by the ILO and the WTO Secretariat explicitly refers to freedom of association and the right to collective bargaining as

"universally recognized Human Rights".
At the same time, the collapse of the Washington Consensus, the mixed track record of "liberal" economic reform in contributing to improvement in living standards in developing countries, and the new economics of globalization reflect a fundamental crisis of confidence in the capacity of economics oriented towards liberalization of global markets to provide a universal "formula" for the attainment of human well-being. ${ }^{4}$ There is an absence today of a plausible, agreed normative economic framework that can inform debates about globalization as well as related domestic reforms. This provides a window of opportunity for international human rights law to supply an alternative normative structure for such a debate. To realize this possibility, rights must be capable of being linked to specific policy options and choices and must be capable of translation into a framework for analyzing the effects of alternative trade and related domestic policies, including alternative possible new rules in trade agreements. The promising work of Armartya Sen on development as freedom may be highly relevant in this regard.

The Declaration on Trade Related Intellectual Property Rights (TRIPS) and Public Health and the Kimberly (Conflict Diamonds) Waiver reflect an unacknowledged debt to human rights consciousness in the WTO. The current Director-General of the WTO, Pascal Lamy, has written about globalization with a human face and his conception of the economic sphere, including the international economic sphere, is deeply routed in the notion of humanity. More recently, a joint study by the ILO and the WTO Secretariat explicitly refers to freedom of association and the right to collective bargaining as "universally recognized Human Rights," urges their respect as such and not just for instrumental reasons of social peace, and refutes with empirical evidence the notion that respect for such rights harms competitiveness. ${ }^{5}$

4 See, for example, D. Rodrik, The Global Governance of Trade as if Development Really Mattered, United Nations Development Programme, 2001.

5 International Labor Office and the Secretariat of the World Trade Organization, "Trade and Employment: Challenges for Policy Research," Geneva, 2007, p. 66ff. 
Reconstructing globalization on the basis of a human rights consciousness, and in particular with a view to fully realizing the vision of the ICESCR is a daunting task which would need to engage many policy disciplines and many institutions. Apparent lack of consensus concerning the legal status and precise meaning of some social and economic rights is an obstacle to their influence in the international trade regime. Transposing a specific meaning to these rights into the terms of international trade negotiations requires a deeper level of cooperation and cross-communication than has so far been evidenced in the reaction within the World Trade Organization to the overtures of international human rights institutions and activists. But how to achieve that deeper level of cooperation and crosscommunication, given the different languages or idioms in which the human rights community and the trade policy community understand the challenges of globalization?

In our view, a short to medium term strategy is needed to identify some fairly precise and specific interconnections between the legal concepts and doctrines in the treaty texts of both regimes. As international lawyers whose collective expertise extends across both regimes, we seek in this brief commentary to conceive the challenge as a legal question of the interaction and interpretation of treaty norms. ${ }^{6}$

When we examine the features of the WTO treaties as legal instruments - as opposed to the way that the trade policy community has often viewed the WTO regime - it quickly becomes evident that the treaties themselves have been structured in many ways so as to ensure that the means adopted in WTO to achieve economic goals are not inconsistent with the human purposes and values intrinsic to the norms in the ICESCR.

The preamble to the WTO Agreement states the purposes of the WTO system in terms that are broadly consistent with the human ends that underlie the rights in the ICESCR:

... raising standards of living, ensuring full employment and a large and steadily growing volume of real income and effective demand, and expanding the production of and trade in goods and services, while allowing for the optimal use of the world's resources in accordance with the objective of sustainable development, seeking both to protect and preserve the environment and to enhance the means for doing so in a manner consistent with their respective needs and concerns at different levels of economic development, Recognizing further that there is need for positive efforts designed to ensure that developing countries, and especially the least developed among them, secure a share in the growth in international trade commensurate with the needs of their economic development ...

\section{Reconstructing globalization on the basis of a human rights consciousness, and in particular with a view to fully realizing the vision of the ICESCR is a daunting task.} A Strategy is needed to
identify some fairly
precise and specific
interconnections between
the legal concepts and
doctrines in the treaty
texts of both regimes.

6 See generally, International Law Commission, "Fragmentation of International Law: Difficulties Arising from the Diversification and Expansion of International Law," Report of the Study Group of the International Law Commission, finalized by Martti Koskenniemi. 
It is difficult to imagine how the progressive fulfillment of economic and social rights could be achieved, particularly in developing countries, without the advancement of the goals stated in the WTO Preamble.

The exercise of interpretation and implementation provides an international law-based means of advancing the consistency of the WTO treaty regime with the ICESCR.
It is difficult to imagine how the progressive fulfillment of economic and social rights could be achieved, particularly in developing countries, without the advancement of the goals stated in the WTO Preamble. And it should be noted that Article 2 of the ICESCR clearly indicates that the responsibility of states is engaged not just individually with respect to the rights of persons on their territory but also with respect to "international assistance and co-operation, especially economic and technical.”

In most cases, the WTO treaties contain exceptions or limitations clauses that allow deviation from trade liberalization rules where the realization of fundamental human values, such as health, is at stake. This approach has not been fully honored or achieved in all respects in existing WTO law, especially in the case of intellectual property rights. Even in these cases, much of the problem, however, is arguably a question of the interpretation of the existing treaty rules in the WTO. In some other instances, on which we shall elaborate, commitments within these rules to address economic and social rights-related concerns have not been properly implemented.

The exercise of interpretation and implementation provides an international lawbased means of advancing the consistency of the WTO treaty regime with the ICESCR, i.e. a means that does not depend on the broader transformation of international economic policy or a political rebalancing of globalization.

With respect to interpretation, the Appellate Body of the WTO has suggested that non WTO legal norms have several uses in WTO dispute settlement:

- to interpret the scope of an exception to a WTO obligation ("exhaustible natural resources" in the Shrimp/Turtle case),

- to articulate a legal benchmark related to the situation of developing countries (the meaning of "development needs" in the EC-GSP case),

- to establish international recognition of a state of affairs (that certain species were endangered in the Shrimp/Turtle case),

- to indicate an appropriate standard of deference or sensitivity to domestic regulatory action (the precautionary principle in the Hormones case). ${ }^{7}$

Art. 31(3)(c) of the Vienna Convention on the Law of Treaties (VCLT) provides that among the mandatory sources of treaty interpretation is "any relevant rules of international law" applicable to the parties." A recent WTO panel, in the US-EC GMOs case, declined to consider an international convention, the Biosafety Protocol, because it read this provision as requiring that all the parties of the WTO be also parties to the Protocol, for it to be considered as an interpretative aid. This narrow approach to 31(3)(c) has been rejected both by the Study Group on Fragmentation of the International Law Commission and by the International Court of Justice in the recent Oil Platforms decision. In any case, the Appellate Body of the WTO has used international law as reflective of broad agreement in the international community even where not

7 For an overview of the WTO dispute settlement cases see: http://www.wto.org/english/tratop_e/dispu_e/ dispu_status_e.htm 
all of the parties to dispute were bound by the instrument in question (the Rio Convention in Shrimp/Turtle) and in one instance where the Appellate Body was uncertain that the rule had yet crystallized into binding hard law (the Precautionary Principle in EC-Hormones). One limit on the use of non-WTO law reflected in the recent Mexico-Soft Drinks case is that the Appellate Body will not on its own make a determination as to whether a particular WTO Member has violated its obligations under a non-WTO legal instrument. This does not significantly narrow the role for non-WTO in interpretation, as normally the issue will not be whether a WTO Member has violated a provision of the ICESCR but what is necessary in terms of relaxation of WTO disciplines for the Member to fulfill its duties under the ICESCR.

There are narrower or more expansive ways of reading the idea of consistency between treaty norms in the ICESCR and those in the WTO. In this commentary, we have chosen to focus on a relatively narrow conception: namely the notion that one treaty regime should not undermine the existing effectiveness of the other; this does not mean that in the longer run it would not be desirable to explore the possibility of restructuring the WTO system to enhance the capacity of states to respect, protect and fulfill the rights in the ICESCR. Our estimate is, however, that the current level of dissensus about the relationship of trade liberalization to economic development, and the divergent views of different states on notions of equity in the WTO system, make this a difficult agenda to pursue for the moment, from the perspective of the UN human rights institutions and the WTO itself.

So instead we have decided to concentrate on a set of situations where the concern is that the WTO treaty regime could operate to undermine ICESCR norms such that the effects would almost universally be viewed as unacceptable by states and peoples with different positions and perspectives on many of the fundamental debates about economic globalization, development and global justice.

Here we avert to the concept of human security, as articulated in the Report of the UN Commission on Human Security (2003): "Human security complements human development by deliberately focusing on downside risks. It recognizes the conditions that menace survival, the continuation of daily life and the dignity of human beings... Human security helps identify the rights at stake in a particular situation. And human rights help answer the question: How should human security be promoted." (p. 10)

A focus on human security so articulated is broadly consistent with the idea of "minimum core obligation" and "minimum essential levels" of economic, social and economic rights, which has been articulated by the Committee on Economic, Social and Cultural Rights. ${ }^{8}$

Making economic, social and cultural rights as they relate to basic human security a priority, and addressing the risk of human security being undermined by the WTO treaty regime is justified not only because of the broad consensus around

8 General Comment No. 3: The Nature of State Parties Obligations, $5^{\text {th }}$ Sess. (1990), ICESCR.

\author{
Human Security: "Human \\ security complements \\ human development by \\ deliberately focusing on \\ downside risks."
}


Where human security itself is threatened by the denial of economic, social and cultural rights, the rights in the Civil and Political Covenant are likely to be menaced or unachievable, as well. human security-related norms, but also due to the fact that the progressive fulfillment of all the rights in the ICESCR clearly depends on social and political conditions that are fundamentally compromised when human security itself is threatened. A minimum of human security is in many ways a pre-requisite for the social cooperation, citizen and worker participation, and good governance that are needed if the full vision of the Covenant is to be achieved in each country. Conversely, when human security is menaced, whether by economic crisis, natural disaster or war, the acquis of social, economic and cultural rights can be rapidly undermined. Moreover, where human security itself is threatened by the denial of economic, social and cultural rights, the rights in the Civil and Political Covenant are likely to be menaced or unachievable, as well.

Not all Members of the WTO are signatories to the Covenant, but in the case of the human-security dimensions of rights such as the right to health to food and to work, even non-signatories of the Covenant have participated in various legal and policy instruments and initiatives that affirm these dimensions, whether the Declaration on core labor rights of the International Labor Organization (ILO) or the Food and Agriculture Organization's (FAO) initiatives on food security, or the World Health Organization's constitution, which affirms the right to health as fundamental. Moreover, the human security dimensions of economic and social rights are arguably already implicit in the notion of the right to life in the Covenant on Civil and Political Rights.

In our view, the connection of the rights in the ICESCR to human security makes these rights something more than provisions of a specialized treaty regime. They form part of what The Report of the Study Group of the ILC refers to as the "normative environment" of the international legal order, which must be taken into account in interpreting and applying particular treaties. ${ }^{9}$ This presupposes that there is a minimum substantive normativity inherent in the international legal order, a kind of foundation or floor, grounding the aspirations and efforts of the international legal system. It is our view that the notion of human security captures this minimum substantive universal normativity. The idea of human security as such a normative floor for the interpretation and application of the WTO treaties is acknowledged in the WTO Appellate Body's suggestion that WTO law must be interpreted and applied in light of the notion that the "preservation of human life and health" is a value that "is vital and important in the highest degree."10

The access to medicines and conflict diamonds examples suggest that the international trade regime would be open to human rights culture as a culture of human security. In the case of access to medicines, the WTO Members were prepared to modify the rights and obligations in TRIPS in order to facilitate affordable access to medications necessary to deal with devastating life-threatening illness. In the case of conflict diamonds, the WTO Members created a waiver that affirmed as a matter of legal certainty that Members could restrict trade in diamonds to conflict areas in a manner consistent with their WTO obligations (this is especially notable,

9 Supra n. 1, para. $415 \mathrm{ff}$.

10 EC-Asbestos, para. 174. This case is discussed below in connection with the right to health. 
because such restrictions could anyhow have been justifiable as an exception under the relevant WTO treaty). These examples show that the WTO as a treaty community is susceptible to concerns of human security.

In our view, there are several dimensions to the downside risk that WTO norms may undermine or be inconsistent with the human security dimensions of social, economic and cultural rights; appreciation of these concrete dimensions allows us to make very concrete suggestions as to how such tensions between treaty regimes can be addressed within the idiom and structures of international law. 


\section{Domestic Policy Space}

Various WTO treaties contain constraints on the ability of WTO Members to use domestic policy instruments.
Various WTO treaties contain constraints on the ability of WTO Members to use domestic policy instruments, whether compulsory licensing in the case of TRIPS, subsidies including food subsidies in the case of the Subsidies and Countervailing Measures (SCM) Agreement and the Agreement on Agriculture, or industrial policy measures such as local content requirements. In addition, WTO Members could bind themselves under the General Agreement on Trade in Services (GATS) to liberalize market access in sectors related to essential services, such as health care and water, limiting in important ways their ability to impose public goals related to the human security dimensions of economic and social rights (such as universal affordable access to clean water) on private economic operators who have a right to participate in the market under the GATS commitments. So far, their have been few commitments negotiated that directly affect such public services; in the current round of negotiations, NGO activists have effectively raised awareness of the risks to policy space, and to human rights, of acceding to demands of some WTO Members for guaranteed market access in these areas.

With respect to policy space, there are several very specific legal challenges posed by these aspects of the WTO regime:

- to ensure that that existing flexibilities in the treaties, including exception and limitation clauses are interpreted so as to allow WTO Members to meet their obligations with respect to human security dimensions of economic and social rights;

- to guarantee the full implementation of flexibilities that have already been added by agreement of WTO Members, for instance those based on the Doha Declaration on TRIPS and Public Health;

- to identify areas where enhanced or new flexibilities are required in order to ensure that WTO Members can meet their obligations with respect to human security dimensions of economic and social rights (for instance, the inclusion of emergency safeguards in the GATS and the creation of a "safe haven" for subsidies necessary for the realization of human security-related human rights);

- to identify with as much precision as possible those instances where proposed new WTO disciplines, including additional commitments to services sector liberalization, may risk constraining policies necessary to realize the human security dimensions of economic, social and cultural rights (the example of water privatization and GATS).

As a general matter, it is important that policy space be understood as a permissive concept: allowing flexibility to a WTO Member to use a particular policy instrument need not imply that this will be the optimal or desirable instrument for realizing a given economic or social right in all contexts. If one takes the example of privatization, in some national contexts, monopolization and privatization of 
essential services may lead to greater access and lower prices, thus helping to fulfill the economic and social rights in question; in others, the effects may be higher prices and less universal access may be compromised.

\subsection{The Direct Effects on Social, Economic and Cultural Rights of Reduction in Trade Barriers}

While the trade policy community has generally assumed that reduction in explicit trade barriers such as tariffs leads to increased overall domestic welfare in WTO Members, more recent economic research has shown that opening up domestic markets to foreign competition leads to social and economic dislocation in many countries; this social and economic dislocation affects the enjoyment of human security dimensions of social and economic rights such as the right to work.

The challenges here we see as follows:

- to facilitate the best possible ex ante analysis of what the likely effects will be in a given country of increased competition from imports due to negotiated reduction of trade barriers, including on particularly vulnerable groups;

- where the overall balance of effects is positive, but there are negative impacts on the enjoyment by some individuals and groups of human security-related dimensions of economic, social and cultural rights, to formulate specific policy strategies to address these possible negative impacts (adjustment policies, for example) and to ensure that such policy responses are permissible under WTO rules (which relates to policy space, as discussed above). Some of the strategies in question may imply agreement on technical assistance or development aid, in the case of developing countries.

- in cases where the negative effects have not been anticipated, to ensure that there is sufficient possibility within the WTO treaty regime for temporary reversal of market opening commitments to deal with effects on human security dimensions of economic, social and cultural rights ("safeguards"), or through actual rebalancing of commitments of the particular WTO Member.

- to evaluate ex post the actual effects of trade liberalization commitments on the enjoyment of human security-related dimensions of economic, social and cultural rights so as to provide a basis where necessary for adjustment of commitments through further multilateral negotiations, where challenges appear to be common to a range of WTO Members.

In the next part of this paper, we proceed to examine aspects of rights in the Covenant that are directly and obviously connected to the concept of human security, and elements of which have been affirmed in terms of legal obligation in a variety of other instruments and institutions. We have chosen the right to work, the right to health and the right to food, although there are others as well, no doubt. Given our international law-based approach, we focus on those aspects of the interaction of the WTO system with these rights that are most closely grounded in existing treaty norms and their interpretation, related commitments and instruments, and matters that are the subject of existing treaty-rule negotiations in the present Doha Round.
Recent economic research has shown that opening up domestic markets to foreign competition leads to social and economic dislocation in many countries. 


\section{The Rights to Work, Health and Food in Interaction with the WTO Regime}

\subsection{The Right to Work}

Article 6 of the Covenant provides:

1. The States Parties to the present Covenant recognize the right to work, which includes the right of everyone to the opportunity to gain his living by work which he freely chooses or accepts, and will take appropriate steps to safeguard this right.

2. The steps to be taken by a State Party to the present Covenant to achieve the full realization of this right shall include technical and vocational guidance and training programmes, policies and techniques to achieve steady economic, social and cultural development and full and productive employment under conditions safeguarding fundamental political and economic freedoms to the individual.

\subsubsection{Human Security, International Trade, and Worker Dislocation}

"The right to work contributes ... to the survival of the individual and to that of his or her family..."
The human security dimension of the right to work has been identified in ICESCR General comment No. 18: "The right to work contributes ... to the survival of the individual and to that of his or her family..." ${ }^{11}$ Loss of employment due to enhanced foreign competition from trade liberalization may threaten survival so understood, unless appropriate adjustment policies are undertaken. It should be recalled that the Preamble of the WTO Agreement affirms the commitment of WTO Members that "their relations in the field of trade and economic endeavour should be conducted with a view to raising standards of living, ensuring full employment and a large and steadily growing volume of real income and effective demand." Both the negotiation and application of WTO rules must be guided by this commitment, inter alia, to full employment and raising standards of living, which may be regarded as having largely incorporated the right to work into the WTO regime (along such lines, in the Shrimp/Turtle case, the Appellate Body found that the reference to "sustainable development" in the Preamble made the international law of biodiversity relevant as a standard for interpreting and applying relevant WTO norms.)

While the optimal policies for moving toward full employment and higher standards of living may be a matter of controversy in the WTO, from a human security perspective on the right to work, there is an obligation to ensure that survivalthreatening job losses due to trade liberalization are predicted and avoided as much as possible through the crafting of trade rules and concessions, and that WTO rules permit to member states the policy space to address the impact on the

11 Economic and Social Council, Committee on Economic, Social and Cultural Rights, "The Right To Work: General comment No. 18," Adopted on 24 November 2005, E/C.12/GC/18, 6 February 2006, paragraph 1. 
right to work through appropriate adjustment policies, such as retraining, education, and income support. This includes the kinds of policies explicitly indicated in 6(2) of the ICESCR. In this respect we note that the Secretariats of both the ILO and the WTO have emphasized the importance of active labour market policies in their recent report on employment and trade: "Active labour market policies may also be a useful tool to facilitate adjustment to changes in the structure of production brought about by trade liberalization. Measures to provide retraining for displaced workers and job search assistance to facilitate labour mobility will be important in this connection." 12 It should be acknowledged that many adjustment policies such as funding for generally available vocational training are entirely consistent with WTO rules; but, as explained below, if policies are targeted at specific sectors or firms with adjustment needs, there is a risk of the policies being viewed as impermissible subsidies.

We see the following as required:

- a serious effort to assess and estimate ex ante the possible negative employment impacts of alternative positions in WTO negotiations, with special attention to the duty of non-discrimination under the Covenant and therefore the distribution of potential employment effects along gender lines as well as the other statuses enumerated in Article 2.3 of the Covenant.

- the provision of technical assistance to states who are unable otherwise to make such estimates

- a structure and timetable to negotiations that permit such assessments to influence the negotiation of concessions and treaty rules in a timely and effective fashion

- effective "safeguard” provisions in WTO Agreements, which allow WTO Members adequate policy space to deal with negative effects of trade concessions on the right to work, especially where the effects have not been predicted or predictable through ex ante assessment.

- a plan by each Member as to how it will safeguard the right to work given anticipated negative employment affects on some sectors due to trade concessions

- Interpretation and perhaps modification of WTO rules on subsidies" and safeguards, and perhaps other rules as well, in order to allow WTO Members to address the threat to human security from trade liberalization-induced job losses (or indeed dislocation for other reasons that threatens human security).

\subsubsection{Subsidies}

Policies that provide a financial contribution to a recipient and a benefit (i.e. a competitive advantage) and that are specific to particular industries or sectors, may be actionable "subsidies" under the WTO Subsidies and Countervailing Measures (SCM) Agreement, depending on their effects on international trade.
The Secretariats of both the ILO and the WTO have emphasized the importance of active labour market policies on employment and trade. Many adjustment policies such as funding for generally available vocational training are entirely consistent with WTO rules. 
Today there are no subsidy programs that are explicitly protected as non-actionable.
The SCM Agreement (Article 8) originally entailed a defined list of subsidies to be deemed "non-actionable," i.e. subsidies immunized from challenge in WTO dispute settlement as well as countervailing duty action, even if they were to be found to meet the criteria discussed above. This list included certain subsidies for research and development, environmental protection, and to disadvantaged regions. However, this provision for deemed non-actionability applied provisionally, for only the first five years that the SCM Agreement was in force. Since its effective expiration, WTO Members have been unable to agree to either continue with the list as it now stands or to create a different list. Therefore, today there are no subsidy programs that are explicitly protected as non-actionable. During the Doha Round negotiations, proposals from developing countries (most notably Venezuela and Cuba) emerged for the reinstatement of a category of non-actionable subsidies.

Based upon the joint work of the ILO and the WTO, and in collaboration with the Committee on Economic, Social and Cultural Rights, it should be possible to draw up a list of policy instruments, including those already mentioned in Article 6 of the ICESCR, that may be necessary for WTO Members to enact, in order to address the human security dimensions of the right to work, and particularly to prevent the threat to human security through loss of employment from trade-liberalization induced industrial dislocation. These policy instruments could form part of a new “non-actionable” category in an amended SCM Agreement in the Doha Round.

Moreover, in the case of those instruments explicitly indicated in Art. 6, any interpretation of the SCM Agreement should be based on a presumption that since most WTO Members were bound by the ICESCR when they negotiated the SCM, that Members deemed the instruments in question consistent with SCM: this derives from the basic international law principle that, to the extent possible the interpretation of one treaty should not render other obligations under other treaties ineffective. This may have significance in the interpretation of specificity, which is a complex judgment not determined by bright line rules. In particular, 2.1(b) of the SCM appears to be aimed at guaranteeing some policy space for subsidies that are provided on the basis of "objective criteria”:

Where the granting authority, or the legislation pursuant to which the granting authority operates, establishes objective criteria or conditions governing the eligibility for, and the amount of, a subsidy, specificity shall not exist, provided that the eligibility is automatic and that such criteria and conditions are strictly adhered to. The criteria or conditions must be clearly spelled out in law, regulation, or other official document, so as to be capable of verification.

Arguably, subsidy measures aimed at realizing the right to work should be deemed to have been understood to fall within the notion of measures based on "objective criteria or conditions," where the features of these programs are reasonably related to the right to work as articulated in Article 6 of the Covenant.

The WTO Trade-Related Investment Measures (TRIMS) Agreement identifies some investment-related measures that are deemed to be impermissible under the WTO. These include measures that require an enterprise to use local content or sourcing in its production activities; such measures are deemed to be inconsistent with 
Article III:4, the National Treatment obligation of the GATT. However, the TRIMS Agreement also provides that the exceptions otherwise applicable to the GATT apply as well in the case of TRIMS that are deemed to violate specific provisions of the GATT. Thus, where a Member needed to impose such requirements in the context of a national economic crisis, for instance, to prevent the enjoyment of the Right to Work being undermined, the measures might be justifiable under Article $\mathrm{XX}(\mathrm{a})$ of the GATT, as necessary for the protection of public morals. In the $U S$ Gambling decision, the Appellate Body referred to public morals in Art. XIV of GATS as concerning "the preservation of the fundamental interests of a society, as reflected in public policy and law.”(See paras 296-299). Almost by definition rights recognized internationally can be considered "fundamental interests ... as reflected in ... law.”

With respect to the Right to Work as it is relevant to employment in service industries, the GATS does not contain any explicit disciplines on subsidies in the context of services. The future negotiation of such provisions is anticipated by Art. XV of GATS, which recognizes the role of subsidies in development programs of developing countries

It has been argued that the National Treatment obligation in the GATS, which prohibits discrimination against like services and service providers of other WTO Members, would make subsidies targeted at local workers questionable. However, a WTO Member might offer subsidies to any service provider with a commercial presence and the capacity to create employment or train workers in the Member concerned.

Article XIX of the GATT provides that a WTO Member may impose "safeguards" on a temporary basis, increasing tariffs above the ceilings it has committed in WTO negotiations, under certain circumstances where a domestic industry is suffering injury due to surges in imports. The definition of injury includes inter alia a situation of declining employment. In light of the right to work the narrow interpretation of safeguards that is prevalent in WTO jurisprudence may need to be re-examined. A strict demonstration that the events leading to the surge of imports could not reasonably have been foreseen has been required by the Appellate Body in order for a member to invoke safeguards, and also a strict demonstration of a casual relation between the surge of imports and the injury. Since it is hard through economic methodology to identify a surge in imports as a factor separate from others affecting the fate of an industry, ${ }^{13}$ the consequence is that safeguard relief is very difficult to come by in the WTO. Horn and Mavroidis have argued that the rationale for safeguards should be seen in significant measure as to address social adjustment costs from trade liberalization. ${ }^{14}$

13 See Gene Grossman and Petros Mavroidis, "United States-Definitive Safeguard Measures for Imports of Circular Welded Carbon Quality Line Pipe From Korea," in Horn and Mavroidis, eds., The WTO Case Law of 2002 (New York and Cambridge: Cambridge Univ. Press, 2005), pp. 122ff.

14 Henrik Horn and Petros Mavroidis, "What Should be Required of a Safeguard Investigation. A discussion of the Appellate Body Report On United States-Safeguard Meaures on Imports of Fresh, Chilled or Frozen Lamb Meat from New Zealand Australia in Horn and Mavrodis, eds., The WTO Case Law of 2001 (Cambridge: Cambridge Univ. Press, 2004).

\section{Article XIX of the GATT provides that a WTO Member may impose "safeguards" on a temporary basis, where a domestic industry is suffering injury due to surges in imports.}


There is an obligation on the state taking safeguards to take other adjustment measures to ensure that the underlying problem is addressed.

The WTO contains a mechanism for examining the trade-related policies of WTO Members and their effects, the Trade Policy Review Mechanism (TPRM).
In light of that consideration, are such readings of the treaty texts in question really required, especially given the right to work, reflected in the "full employment" objective stated in the WTO Agreement Preamble? Of course, safeguards may have negative impacts on the right to work in the countries of export that are now faced with higher tariffs. However, there are other facets that balance this concern of the exporting country with the concern for adjustment of the importing country and its workers. These include the requirement that safeguard relief be temporary and that compensation be offered to affected exporting states. Also, there is an obligation on the state taking safeguards to take other adjustment measures to ensure that the underlying problem is addressed. A proper understanding of the right to work could be relevant to defining appropriate compensation, determining whether there is an ongoing justification for safeguards, and what alternative adjustment policies a Member can be expected to take to address the underlying situation.

In this context, it should be noted that the WTO contains a mechanism for examining the trade-related policies of WTO Members and their effects, the Trade Policy Review Mechanism (TPRM). The function of the TPRM is stated as the "impact of a Member's trade policies and practices on the multilateral trading system". As already noted, the WTO Agreement (to which the TPRM treaty is annexed) states as an objective of the WTO, inter alia, that "relations in the field of trade and economic endeavour should be conducted with a view to raising standards of living, ensuring full employment and a large and steadily growing volume of real income and effective demand." The references to "raising standards of living" and "full employment" suggest that the mandate of the TPRM should include a consideration of the effects of trade and related policies, including those implementing WTO rules, on the realization of the right to work. But this turns out not to be the case. Take for example, the Trade Policy Review of Senegal earlier in this decade. The Secretariat report does note policies of Senegal that have impacts on the realization of the objectives in the WTO Preamble, including positive initiatives to enhance educational and workforce opportunities for women. ${ }^{15}$ On the other hand, neither does the report consider how Senegal's trade and related policies, such as privatization may either enhance or threaten such initiatives, which have obvious relevance to the right to work.

\subsubsection{Human Security, Trade in People, and the General Agreement on Trade in Services}

While the above discussion has focused, in relation to the right to work, on the risk to human security from loss of employment opportunities, human security can also be threatened by certain conditions of work. The right to work has important implications for the situation of migrant and trafficked ${ }^{16}$ workers, for example, whose treatment often raises issues of human security. Under the WTO

15 See International Confederation of Free Trade Unions, "Internationally Recognized Core Labour Standards in Niger and Senegal”, Geneva 22-24 September 2003.

16 The concept of trafficking includes not only obviously non-consensual movement of workers (with coercion or threat of force) but also movement that constitutes exploitation, which would include subjection to employment conditions threatening to human security, i.e. denial of the minimum human conditions of work as required by the core content of ICESCR Article 6. See Jacqueline Babha, "Trafficking, Smuggling and Human Rights," Migration Policy Institute, March 12005. 
GATS liberalization of trade in services includes so called Mode 4 trade, the temporary physical presence of the service provider in the host country. The characterization of persons who temporarily go to another WTO Member country for purposes of employment as transboundary "service providers" rather than workers raises the issue of whether it is an assumption of GATS that such persons are to be exempt from the protections of labor or human rights regulation, either in the host or the home country or both.

Under the GATS so far there have been only limited commitments by individual WTO Members to liberalize Mode 4 services trade. There is thus the opportunity for human rights institutions to focus on the relationship of such commitments to the right to work, providing guidelines on how WTO Members should define such commitments in light of their obligation with respect to the right to work-at a minimum, in such a way as to not further undermine the human security of migrant and trafficked workers. For example with respect to the existing commitments under GATS, Caroline Dommen notes: "Most countries that have made GATS Mode 4 commitments also provide for wage and labor standard parity [with indigenous workers]. Over 50 WTO members have included the wage-parity stipulation in their Mode 4 commitments. In addition, to prevent foreign "strike breakers," 22 members have reserved the right to suspend Mode 4 commitments in the event of labor-management disputes." ${ }^{17}$ Building upon these individual country experiences with scheduling commitments, it would be useful for the ILO, the WTO and UN bodies concerned with migration and trafficking to collaborate on a set of guidelines for scheduling future commitments under GATS mode IV in order to protect the human security of migrant or trafficked workers. This might include the possibility of excluding from commitments altogether sectors or sub-sectors where trafficking is rampant.

At the same time, even apart from the specific commitments that WTO Members make with respect to Mode 4 under GATS, the Most-Favoured Nation clause applies generally to all services trade. This means that, whether or not it has made specific commitments, a WTO Member cannot discriminate between different countries in its approach to regulating services. This raises the issue of whether, even if it hadn't made any specific commitments, a WTO Member could restrict or prohibit trade in workers from a country that is not taking effective measures to deal with trafficking problems. Presumably here the public morals exception to GATS obligations could be invoked (Article XIV a). The right to work might be used as part of the normative context for interpreting this exception. Again, since there is little awareness or attention in the WTO to the situation of migrant and trafficked workers, it is important that the relevant agencies provide guidance as to appropriate measures for addressing the human security of such persons, to ensure that the GATS is interpreted in a manner that allows such measures to be taken and to be effective.
GATS liberalization of trade in services includes so called Mode 4 trade, the temporary physical presence of the service provider in the host country.
It would be useful for the ILO, the WTO and UN bodies concerned with migration and trafficking to collaborate on a set of guidelines for scheduling future commitments under GATS mode IV. 


\subsection{The Right to Health}

Article 12 of the ICESCR provides:

1. The States Parties to the present Covenant recognize the right of everyone to the enjoyment of the highest attainable standard of physical and mental health.

2. The steps to be taken by the States Parties to the present Covenant to achieve the full realization of this right shall include those necessary for:

(a) The provision for the reduction of the stillbirth-rate and of infant mortality and for the healthy development of the child;

(b) The improvement of all aspects of environmental and industrial hygiene;

(c) The prevention, treatment and control of epidemic, endemic, occupational and other diseases;

(d) The creation of conditions which would assure to all medical service and medical attention in the event of sickness.

\subsubsection{Trade in Goods}

A fundamental aspect of the right to health is the duty of the state to protect against disease and related health risks.

Several WTO treaties have provisions that could limit the ability of WTO Members to discharge their duty under Article 12(2)(c) of the Covenant.
A fundamental aspect of the right to health is the duty of the state to protect against disease and related health risks-especially, from a human security perspective those that are life-threatening or can result in a fundamentally reduced capacity to live with dignity. As the dramatic examples of avian flu and mad cow disease illustrate, in an era of globalization threats to health security can spread across national boundaries at breakneck pace, through the movement of goods and natural persons.

Several WTO treaties have provisions that could limit the ability of WTO Members to control the entry and conditions of sale of imported products in order to discharge their duty under Article 12(2)(c) of the Covenant.

In the EC-Asbestos case, Canada challenged a health-based ban by France on all asbestos and asbestos-containing products, whether domestic or imported. The panel held that asbestos and asbestos-containing products were "like" substitute products on the domestic market in France, and therefore that France had violated Art. III:4, the National Treatment provision, which requires that "like" domestic and imported products be treated even-handedly. In effect, the panel was saying that a product that has a long history of causing loss of human life has to be treated under WTO law the same as a non-lethal substitute, for the sake of free trade. The Appellate Body reversed this ruling, finding that the panel erred in law in deciding that health effects could not be taken into account in the determination of likeness, and went on to find that, on account of the different health effects that stemmed from the different physical characteristics of, respectively, asbestos and substitute products that were permitted in France, these two groups of products were "unlike": there was thus no violation of National Treatment. From the perspective of the Right to Health, this is a landmark ruling, because it indicates that considerations of health as a human value must be considered not only in interpreting and applying exceptions to WTO disciplines, but in understanding the very scope of those disciplines themselves. Even where an exception exists - as it does for measures necessary to protect, inter alia, human health - at the same 
time WTO Members should not be lightly assumed to have undertaken in the first place substantive obligations that are inconsistent with the Right to Health, when those obligations can be read and applied otherwise, consistent with the rules of interpretation in the Vienna Convention on the Law of Treaties (VCLT).

In this respect, it is significant that the Appellate Body went on, even though it had already reversed the panel's finding of a violation of III:4, to make a point of indicating that France's measure would in any case have been justified under the health exception in Article XX. In so doing, the Appellate Body noted that: "it is undisputed that WTO Members have the right to determine the level of protection of health that they consider appropriate in a given situation.” Further the Appellate Body held: “ [in a previous case we found] “[t]he more vital or important [the] common interests or values" pursued, the easier it would be to accept "necessary" measures designed to achieve those ends. [footnote omitted] In this case, the objective pursued by the measure is the preservation of human life and health through the elimination, or reduction, of the well-known, and life-threatening, health risks posed by asbestos fibres. The value pursued is both vital and important in the highest degree."(para. 172)

It is clear that where the WTO adjudicator concludes that "the value pursued is both vital and important in the highest degree" an additional degree of deference will be afforded to domestic regulatory action aimed at vindicating the value in question: this in itself suggests a particular role for the rights in the Covenant. By binding themselves to respect, protect and fulfill economic, social and cultural rights, the parties to the Covenant evidence the acceptance of the human values underlying the rights as fundamental - having priority over less fundamental, or secondary, human interests.

\subsubsection{Domestically-Prohibited Products}

The issue of domestically prohibited products illustrates the complexity of the Right to Health in relation to WTO disciplines. Art. XI of the GATT bans restrictions and prohibitions on exports. Where a WTO Member prohibits the sale of a product on grounds of health risks, the member may enact such a ban without regard to whether the sale is domestic or for export. In such a situation where the measure is not targeted at exports in particular would that aspect nevertheless violate Art. XI? From a right to health perspective, such a prohibition as applied to exports could be seen as a fulfillment of the duty to engage in international cooperation to fulfill the right to health. Developing countries, which may have limited resources and capacities to detect health risks when products cross the border have expressed concern about developed countries exporting products viewed as dangerous to health in domestic regulation-a kind of dumping. According to the Special Rapporteur on the Right to Health, "Sometimes drugs, rejected in the North because they have passed their expiry date, are sold in the South. Thus, States need to have in place a basic system for monitoring essential drug quality ... The duty to respect requires States to refrain from interfering, directly or indirectly, with the enjoyment of the right to health. Thus, a State should not market unsafe drugs..."18

18 Commission on Human Rights, Sixtieth Session, "The right of everyone to the enjoyment of the highest available standard of physical and mental health: Report of the Special Rapporteur, Paul Hunt: Addendum, Mission to the World Trade Organization, E/CN.4/2004/49/Add. 1, 1 March 2004, para. 38-40.
The Appellate Body noted that: "it is undisputed that WTO Members have the right to determine the level of protection of health that they consider appropriate in a given situation."

The issue of domestically prohibited products illustrates the complexity of the Right to Health in relation to WTO disciplines. 
The logic of a humanitybased conception of international law is that the obligations of human rights are not limited to a state's own citizens.
However, on some scenarios the imposition of export controls based on domestic regulatory approaches could undermine the country of importation's ability to decide on what is required to protect the right to health of its own citizens. Take the example of new experimental medications to treat HIV/AIDS. In countries such the US such medications may be only available legally on the market after years of clinical trials to ensure their relatively benign effect on human health. Another country's government may determine however that the right to health requires allowing patients access to such novel treatments more rapidly-especially if their health condition is grave in the short term. The logic of a humanity-based conception of international law is that the obligations of human rights are not limited to a state's own citizens. However the ICESCR affirms a norm of self-determination, suggesting that each society is entitled to a large degree of autonomy in realizing its course of social and economic development.

The issues raised by export of domestically prohibited products have not received any definitive treatment in the WTO itself ${ }^{19}$ : there is a gap here, as the treaty texts do not seem to explicitly address this dilemma, and thus an opportunity to frame this issue, inasmuch as it relates to human health, in terms of the Right to Health.

\subsubsection{The Right to Health, the TRIPS Agreement, and Access to Essential Medicines}

Article 31 of TRIPS provides the flexibility for WTO Members to compulsory-license patents, where certain conditions are met, including reasonable compensation to the rights-holder, and provided the license only applies to the market of the WTO Member in question. Despite this flexibility, which is even greater where an emergency situation exists (some of the conditions are lifted), drug industry interests and some developed-country governments tried to discourage developing countries who sought to use this flexibility to address the health crisis of HIV/AIDS, by taking an extremely narrow view of the flexibilities in question. The TRIPS division of the WTO Secretariat appears to have largely collaborated in this undertaking, sending a message as to the strictness of TRIPS disciplines, and underemphasizing the flexibilities.

The TRIPS Agreement does not and should not prevent Members from taking measures to protect public health.
In response, the WTO Doha Declaration on Access to Medicines, made clear that the TRIPS Agreement should not provide obstacles to the availability of essential medicines at affordable prices, at least in relation to certain critical diseases. Article 4 reads: 'We agree that the TRIPS Agreement does not and should not prevent Members from taking measures to protect public health. Accordingly, while reiterating our commitment to the TRIPS Agreement, we affirm that the Agreement can and should be interpreted and implemented in a manner supportive of WTO Members' right to protect public health, and in particular, to promote access to medicines for all.' Article 5 of the Declaration specifies some of the specific implications of this affirmation, 'including the right to grant compulsory licenses and the freedom to determine what constitutes a national emer-

19 All the issue is largely unaddressed in the scholarly literature, with the rare exception of Tobias Bender, "Unilaterale Exportverbote von Domestically prohibited goods zum Umwelt- der Gesundheitsschutz im Ausland und ihre Rechtmäßigkeit nach dem GATT ein Betrag zur Dogmatik der Artikel 11 und XX GATT," Zeitschrift für ausländisches öffentliches Recht und Völkerrecht (2003), 4, 1007-1034. 
gency or other circumstances of extreme urgency, it being understood that public health crises, including those relating to HIV/AIDS, tuberculosis, malaria and other epidemics, can represent a national emergency or other circumstances of extreme urgency'.

In the debate over the usefulness of compulsory licensing as an instrument to ensure affordable access to essential medicines, it was widely put about that Article 31 of TRIPS did not cover a situation where a developing country wanted to grant a compulsory license in respect of a drug it was importing, i.e. manufactured in another country. Thus, if an African country with no indigenous capacity wanted to import for its domestic market a generic from India, it could not, it was believed, use Article 31. Only India could grant a compulsory license for the Indian domestic market, according to the terms of Article 31. This is true as far as it goes, but it ignores the Article 30 exception in TRIPS. There are good reasons to think that the granting of a compulsory license could be extended to the market in another WTO Member country as an Article 30 exception, where that other WTO Member indicates that were it to possess its own manufacturing capacity, it would itself have granted such a license for production of generics domestically. Such an exception does not conflict with normal exploitation of the patent, in the sense that the government of the importing state would be entitled to limit anyhow the patent-holder's right through compulsory licensing, and the only thing that prevents it from doing so is current lack of manufacturing capacity domestically. It would not fundamentally undermine the patent holder's legitimate interests because, in the case of a poor country, the amount of revenue foregone would not be substantial, and in any case the country granting the license (India) would still have to comply with various conditions (albeit mitigated by the emergency nature of the situation in the case of HIV/AIDS drugs). For these reasons, in our view, the problem of a poor country not having domestic manufacturing capacity could be solved within the four corners of TRIPS.

However, especially in light of various interpretations issued by the industry and to some extent from within the WTO Secretariat, many developing countries wanted additional legal security on this point. Thus, Article 6 of the Declaration provides: 'We recognize that WTO Members with insufficient or no manufacturing capacities in the pharmaceutical sector could face difficulties in making effective use of compulsory licensing under the TRIPS Agreement. We instruct the Council for TRIPS to find an expeditious solution to this problem and to report to the General Council before the end of 2002.' The resulting agreement, as Correa explains, 'takes the form of an interim waiver, which allows countries producing patented products under compulsory license to export the products to eligible importing countries, provided that a compulsory license has also been granted in the importing country'. ${ }^{20}$ According to Correa, however, this solution is not very practicable, given all the onerous conditions that must be fulfilled to take advantage of the waiver, including the requirement that the product for export be clearly distinguishable from the patented version in appearance ('shape, coloring, labeling and packaging'), and the provision of exact information about the
There are good reasons to think that the granting of a compulsory license could be extended to the market in another WTO Member country.

The problem of a poor country not having domestic manufacturing capacity could be solved within the four corners of TRIPS.

20 Carlos Correa, “Access to Drugs Under TRIPS: a not so expeditious solution,” BRIDGES 8/1 (2004), pp. 21-22. 
quantities being produced and shipped, as well as imposing responsibility on the generic producer for proving the 'bio-equivalence' of the generic product and the possibility, if data are not disclosed by the patent-holder, that it would have to conduct its own toxicity and efficacy studies. In Correa's view, these various conditions entail such costs for generic manufacturers that the solution will be of no practical benefit to poor countries who lack their own manufacturing capacity. Moreover, whether a developing country does or does not have such capacity is not a matter of self-declaration, but is subject to challenge, if a developed WTO Member for instance questions the actual existence of incapacity.

Correa's skepticism seems vindicated by virtue of the fact that not a single importing country has declared its intention to use the mechanism. A recent Oxfam briefing paper notes:

Rich countries, for their part, seem to be in no hurry to make it work. Many have been slow to implement the deal, and no country has successfully used the mechanism to export medicines to countries with insufficient manufacturing capacity. The USA has not enacted legislation to implement the solution, while the European Union only approved regulations implementing the public health solution in mid-2006.

Rich countries that did implement the law made it more complicated. Despite the efforts of civil-society groups and generic manufacturers, Canada enacted legislation that has proved 'unworkable' according to Médecins Sans Frontières, which spent two years trying to export generic ARVs under Canada's legislation. The inability of the Paragraph 6 solution to deliver medicines is a serious threat to the legitimacy of the WTO. The current WTO Director-General has just started to acknowledge the solution's present weakness. Civil-society skepticism towards Paragraph 6 is shared by most countries. By October 2006, only three countries, the USA, Switzerland, and El Salvador, had formally accepted the solution. ${ }^{21}$

The Special Rapporteur on the Right to Health noted in 2004: “...the effectiveness of the Decision [on Implementation of Paragraph 6] will depend on the extent to which it actually does lead to increased access to medicines for the poor."22 The failure to implement adequately the decision, and the nature of the measures taken by WTO Members pursuant to the Decision should arguably be examined in depth from the perspective of the Right to Health; here we are dealing with the frustration of rights under WTO law acquired after protracted negotiations, which has clearly negative consequences for human security-dimensions of the Right to Health.

21 Oxfam International, “Patents versus Patients: Five Years After the Doha Declaration”, Oxfam Briefing Paper \#95, 1996, section 5.

22 Commission on Human Rights, Sixtieth Session, "The right of everyone to the enjoyment of the highest available standard of physical and mental health: Report of the Special Rapporteur, Paul Hunt: Addendum, Mission to the World Trade Organization, E/CN.4/2004/49/Add. 1, 1 March 2004, para. 43. 


\subsection{The Right to Food}

Article 12 of the Covenant provides:

1. The States Parties to the present Covenant recognize the right of everyone to an adequate standard of living for himself and his family, including adequate food, clothing and housing, and to the continuous improvement of living conditions. The States Parties will take appropriate steps to ensure the realization of this right, recognizing to this effect the essential importance of international co-operation based on free consent.

2. The States Parties to the present Covenant, recognizing the fundamental right of everyone to be free from hunger, shall take, individually and through international co-operation, the measures, including specific programmes, which are needed:

(a) To improve methods of production, conservation and distribution of food by making full use of technical and scientific knowledge, by disseminating knowledge of the principles of nutrition and by developing or reforming agrarian systems in such a way as to achieve the most efficient development and utilization of natural resources;

(b) Taking into account the problems of both food-importing and food-exporting countries, to ensure an equitable distribution of world food supplies in relation to need.

General comment 12 on the right to food defines the responsibilities of states at the international level among others: (a) to respect the right to food in other countries; b) to facilitate access to food and to provide the necessary food aid when required, but in a manner that does not adversely affect local producers and markets and c) to ensure that in international agreements the right to food is given adequate consideration. ${ }^{23}$

A 2002 Report of the Office of the UN High Commissioner for Human Rights (OHCHR) considered in depth the implications of agricultural trade rules and negotiations in the WTO for, inter alia, the right to food. ${ }^{24}$ Determining an optimal set of international trade rules from the perspective of fully realizing the right to food is a daunting task: the accessibility of food at affordable prices and adequate nutritional quality may depend on a careful balance of elements of local capacity and self-sufficiency and open and competitive world markets. The current rules in the WTO Agreement on Agriculture may not strike such a balance, requiring too much liberalization of developing countries' agricultural markets that threatens local capacity and self-sufficiency, on the one hand, and not requiring sufficient liberalization of developed country agricultural markets, on the other. ${ }^{25}$ But the negotiations on agriculture in the Doha Round reflect considerable controversy and uncertainty as to the best mix of liberalization commitments and safeguards of some aspects of local production.

23 Committee on Economic, Social and Cultural Rights, General comment No. 12, The Right to Food, E/C. 12/1999/5.

24 Globalization and its impact on the full enjoyment of human rights Report of the High Commissioner for Human Rights submitted in accordance with Commission on Human Rights resolution 2001/32,E/ CN.4/2002/54.

25 See for example, United Nations Economic and Social Council, Commission on Human Rights, Report of the Special Rapporteur on the right to food, Jean Ziegler, E/CN.4/2006/44, 16 March 2006, para.40. 
Whatever the overall design of agricultural trade liberalization in the WTO may be, there need to be certain specific legal safeguards or mechanisms to protect the right to food.
Even apart from the challenge of devising an optimal set of rules to promote food security through agricultural trade liberalization, however, there is, from a human security perspective, the more basic, and arguably less controversial challenge of ensuring that whatever set of rules is in place does not have negative effects, including short-term effects, on the realization of the right to food, and that governments remain able to discharge their responsibilities with respect to the right to food through direct policies such as consumer subsidies that ensure that food is affordable to their citizens despite price fluctuations on world markets. Along similar lines, the WTO rules concerning export subsidies on agricultural products must be compatible with the proper role of food aid in assuring the right to food. In other words, whatever the overall design of agricultural trade liberalization in the WTO may be, there need to be certain specific legal safeguards or mechanisms to protect the right to food in its most basic human-security related dimensions.

Although not articulated in terms of the right to food, the Marrakesh Decision that accompanied the Uruguay Round Agreement on Agriculture reflects a recognition of this need for specific safeguards and mechanisms. Because Net Food-Importing Developing Countries (NFIDCs) may experience higher food prices due to the reduction of export subsidies as required in the Agreement on Agriculture, special mechanisms are to be made available under the Marrakesh decision to counter such negative effects, including the establishment of financing mechanisms to ensure affordable accessibility of imported food. As well, a new Food Aid Convention was to be established, to lay down appropriate criteria for the granting of food aid consistent with WTO rules (The Convention came into force in 1999).

It is widely acknowledged that a number of the specific mechanisms envisaged by the Marrakesh Decision have never been implemented, in particular those requiring compensation or financial assistance to NFIDCs. Despite concerns expressed by the FAO and UNCTAD, both the IMF and the WTO have apparently decided not to move forward on such assistance. ${ }^{26}$ The effects of the failure to implement the Marrakesh Decision on the right to food deserve urgent attention: the undertakings in the Decision were integral to the bargain on agricultural trade liberalization negotiated in the Uruguay Round.

Moreover, in 2007 the Food Aid Convention is up for renegotiation. It is important that proposals for modification of the convention, concerning issues such as the degree of concessionality of food aid and targeting of food aid, be examined carefully from the perspective of the right to food.

Thinking in the WTO on the question of food aid is apparently moving in the direction of an approach that would only permit an exception or carve out for food aid in situations of emergency.
Thinking in the WTO on the question of food aid is apparently moving in the direction of an approach that would only permit an exception or carve out for food aid in situations of emergency. ${ }^{27}$ The question is whether such an approach would be consistent with the responsibilities of states in respect of food aid under the right to food: would such a constraint impede the delivery of food aid to prevent or forestall an emergency occurring, requiring that human disaster have already

26 Kevin Gray, "Right to Food Principles vis a vis Rules Governing International Trade”, British Institute of International and Comparative Law, December 2003, p. 27.

27 Chair's Reference Paper, Food Aid. Committee on Agriculture, Special Session, Geneva, April 2006. 
taken place in order for aid to be permissible? From a human security perspective, can emergencies be distinguished from situations in a number of developing countries where the human security of people is threatened on a daily basis by lack of access to adequate food? In any case, attention to the impact on the right to food of evolution of rules on food aid in the Food Aid Convention and the WTO with the right to food is clearly warranted from a human security perspective. 


\section{Conclusion}

\author{
We believe that human \\ security (understood as \\ the protection of human \\ life and health) as a \\ fundamental value has \\ already been recognized in \\ various provisions of the \\ WTO Agreements.
}

It is often suggested that there is a profound normative tension between the regime of human rights on the one hand and that of the WTO on the other. The authors of this paper, both international lawyers, each with a specialization in one of the two regimes, do not believe that the issue should be conceived as one of conflicting legal rights and obligations. The problem stems largely from the historical isolation of the institutional culture of the trade regime from that of the human rights regime. The challenge, both intellectual and practical, is to end this isolation, such that the interpretation and evolution of the norms of the one regime are conducted in a manner that is consistent with the norms of the other.

With this challenge also comes an extraordinary opportunity to provide, in a postCold War context, an orientation for the international trade system that is based on widely agreed norms of human rights and humanity; in the absence of such an orientation, the future evolution of the trading system is likely to be hostage to conflicting national and regional interests and perspectives, especially after the collapse of the Washington consensus, and the accompanying scepticism -including among leading economists themselves - about the ability of economics to provide a general formula for development.

In this "Occasional Paper", the authors have chosen to focus on aspects of the ICESCR that clearly bear on human security and their interrelationship with WTO treaty norms, both in respect to the interpretation of existing rules and in the context of the continuing evolution of those rules. We believe that human security (here understood in terms of the protection of human life and health) as a fundamental value has already been recognized in various provisions of the WTO Agreements and in their interpretation by the Appellate Body.

As international lawyers, we have sought to focus in particular on the compatibility of different treaty norms and regimes, based on the notion that the avoidance of conflict of norms, and the imperative to give effectiveness to all international obligations are fundamental principles of the international legal system. This approach leads to the identification of a select number of very concrete issues that may be pursued by the UN human rights institutions with respect to the WTO system, going beyond open-ended debate and speculation about the overall relationship between human rights and globalization.

We believe that it is through consideration of specific relationships between treaty norms and their interpretation that concern for economic, social and cultural rights can most effectively penetrate the rather isolated institutional culture of the WTO. 


\section{List of Abbreviations and Acronyms}

\begin{tabular}{|c|c|}
\hline AIDS & Acquired Immune Deficiency Syndrome \\
\hline EC & European Communities \\
\hline FAO & Food and Agriculture Organization \\
\hline GATS & General Agreement on Trade in Services \\
\hline GATT & General Agreement on Tariffs and Trade \\
\hline GMOs & Genetically Modified Organisms \\
\hline GSP & Generalized System of Preferences \\
\hline HIV & Human immunodeficiency virus \\
\hline HRW & Human Rights Watch \\
\hline ICESCR & International Covenant on Economic, Social and Cultural Rights \\
\hline ILC & International Law Commission \\
\hline ILO & International Labour Organization \\
\hline $\mathrm{IMF}$ & International Monetary Fund \\
\hline NFIDCs & Net Food-Importing Developing Countries \\
\hline OHCHR & Office of the High Commissioner for Human Rights \\
\hline SCM & Subsidies and Countervailing Measures \\
\hline TRIMS & Trade-Related Investment Measures \\
\hline TRIPS & Trade Related Intellectual Property Rights \\
\hline UNCTAD & United Nations Conference on Trade and Development \\
\hline US & United States of America \\
\hline VCLT & Vienna Convention on the Law of Treaties \\
\hline WTO & World Trade Organization \\
\hline
\end{tabular}





\section{Further Occasional Papers:}

№ 1 / December 2002

New Steps to Faster and Broader Debt Relief for Developing Countries

№ 2 / January 2003

Pedro Morazán:

Deuda externa: Nuevas crisis, nuevas soluciones?

No 3 / March 2003

Money Laundering and Tax Havens:

The Hidden Billions for Development

№ 4 / April 2003

Michaela Eglin

The General Agreement on Trade in Services (GATS) -

A Background Note

№ 5 / April 2003

Sophia Murphy

The Uruguay Round Agreement on Agriculture

and its Renegotiation

$N^{\circ} 6 /$ May 2003

Eva Hartmann / Christoph Scherrer:

Negotiations on Trade in Services -

The Position of the Trade Unions on GATS

№ 7 / July 2003

Brigitte Young / Hella Hoppe

The Doha Development Round, Gender and Social Reproduction

No 8 / July 2003

Eric Teo Chu Cheow

Privatisation of Water Supply

№ 9 / October 2003

Katherine A. Hagen

Policy Dialogue between the International Labour

Organization and the International Financial Institutions:

The Search for Convergence

№ 10 / October 2003

Jens Martens

Perspectives of Multilateralism after Monterrey

and Johannesburg

№ 11 / October 2003

Katherine A. Hagen

The International Labour Organization:

Can it Deliver the Social Dimension of Globalization?

No 12 / March 2004

Jürgen Kaiser / Antje Queck

Odious Debts - Odious Creditors? International Claims on Iraq

No 13 / January 2005

Federico Alberto Cuello Camilo

What makes a Round a 'Development Round'?

The Doha Mandate and the WTO Trade Negotiations

№ 14 / January 2005

Thomas $\mathrm{G}$. Weiss

Overcoming the Security Council Reform Impasse

The Implausible versus the Plausible

NNo 15 / February 2005

Gert Rosenthal

The Economic and Social Council of the United Nations.

An Issues Papier

№ 16 / March 2005

Thomas Greven

Social Standards in Bilateral and Regional Trade and Investment Agreements - Instruments, Enforcement, and

Policy Options for Trade Unions
NN 17 / April 2005

Maria Floro and Hella Hoppe

Engendering Policy Coherence for Development -

Gender issues for the global policy agenda in the year 2005

No 18 / May 2005

Dirk Messner, Simon Maxwell, Franz Nuscheler, Joseph Siegle

Governance Reform of the Bretton Woods

Institutions and the UN Development System

No 19 / May 2005

Luke Eric Peterson

The Global Governance of Foreign Direct Investment: Madly Off in All Directions

N² 20 / August 2005

Nils Rosemann

The UN Norms on Corporate Human Rights

Responsibilities. An Innovating Instrument to Strengthen

Business' Human Rights Performance

$N^{\circ} 21$ / October 2005

Christoph Zöbel

Global Democracy in the Nexus of Governments,

Parliaments, Parties and Civil Cociety

No22 / April 2006

Theodor Rathgeber

UN Norms on the Responsibilities of Transnational Corporations

No23 / July 2006

Felix Kirchmeier

The Right to Development - where do we stand?

State of the debate on the Right do Development

No 24 / August 2006

Jochen Steinhilber

China - A new actor in the Middle East and North Africa Region

$N^{\circ} 25$ / September 2006

Jochen Steinhilber

„Bound to Cooperate?" Security and regional cooperation

№ 25 / September 2006

Jochen Steinhilber

„Bound to Cooperate?" Sicherheit und regionale Kooperation

№ 26 / November 2006

Luke Eric Peterson

South Africa's Bilateral Investment Treaties -

Implications for Development and Human Rights

№ 27 / November 2006

Mahnaz Malik

Time for a Change: Germany's Bilateral Investment Treaty

Programme and Development Policy

No 28 / December 2006

Thomas G. Weiss and Peter J. Hoffman

A Priority Agenda for the Next UN Secretary-General

№29 / December 2006

Jens Martens

Multistakeholder Partnerships -

Future Models of Multilateralism? 
On the author:

Robert Howse is Alene and Allan F. Smith Professor of Law at the University of Michigan. He has also taught at Harvard, Tel Aviv, Toronto, Tsing Hua, and Paris (Sorbonne-Pantheon) Universities and is a regular instructor at the World Trade Institute, Berne. In 2007-2008 he will be a visiting professor at Fordham University (fall) and New York University School of Law (Spring) He is the author, among other works, of The Regulation of International Trade (with Michael Trebilcock), a contributor to the American Law Institute project on WTO Law, and series editor for Oxford University Press's Commentaries on the WTO Treaties.

Ruti G. Teitel is the Ernst C. Stiefel Professor of Comparative Law at New York Law School. She has also taught in the School of International and Public Affairs at Columbia University and at Yale Law School, as a Senior Fellow at the Orville H. Schell, Jr. Center for International Human Rights. Her book, Transitional Justice (Oxford University Press, 2000), examines the 20th century transitions to democracy in many countries. She also writes on human rights issues for a broader audience, having published in The New York Times, Legal Affairs, and Findlaw.com. She is a member of the Council on Foreign Relations, and is also on the Steering Committee of Human Rights Watch Europe/Central Asia, as well as HRW's Terrorism and Counter-Terrorism Steering Committee.

For further information on Dialogue on Globalization, please contact:

Friedrich-Ebert-Stiftung Berlin Hiroshimastrasse 17

D-10785 Berlin

Tel.: ++49-30-26-935-914

Fax: ++49-30-26-935-959

Roswitha.Kiewitt@fes.de www.fes.de

www.fes.de/globalization
Friedrich-Ebert-Stiftung Geneva Office

Chemin du Point-du-Jour 6 bis $\mathrm{CH}-1202$, Geneva

Tel.: ++41-22-733-3450

Fax: ++41-22-733-3545

fes.geneva@econophone.ch

www.fes-geneva.org
Friedrich-Ebert-Stiftung New York Office 747 Third Avenue, 22b New York, N.Y. 10017 Tel.: ++1-212-687-0208 Fax: ++1-212-687-0261 fesny@fesny.org www.fesny.org 